Decomposition of Scots pine fine woody debris in boreal conditions : implications for estimating carbon pools and fluxes

\title{
Vavrova, Petra
}

2009

Vavrova , P , Penttilä , T \& Laiho, R 2009 , ' Decomposition of Scots pine fine woody debris in boreal conditions : implications for estimating carbon pools and fluxes ', Forest Ecology and Management , vol. 257 , no. 2 , pp. 401-412 . https://doi.org/10.1016/j.foreco.2008.09.017

http://hdl.handle.net/10138/27407

https://doi.org/10.1016/j.foreco.2008.09.017

acceptedVersion

Downloaded from Helda, University of Helsinki institutional repository.

This is an electronic reprint of the original article.

This reprint may differ from the original in pagination and typographic detail.

Please cite the original version. 


\title{
Decomposition of Scots pine fine woody debris in boreal conditions: Implications for estimating carbon pools and fluxes
}

\author{
Petra Vávřová ${ }^{1)}{ }^{2)}$, Timo Penttilä ${ }^{2)}$ and Raija Laiho ${ }^{1)}$ \\ 1) Peatland Ecology Group, Department of Forest Ecology, University of Helsinki, P.O. Box \\ 27, FIN-00014 Helsinki University, Finland \\ 2) Finnish Forest Research Institute, Vantaa Research Unit, P.O. Box 18, FIN-01301 Vantaa, \\ Finland
}

\begin{abstract}
Litter quality and environmental effects on Scots pine (Pinus sylvestris L.) fine woody debris (FWD) decomposition were examined in three forestry-drained peatlands representing different site types along a climatic gradient from the north boreal (Northern Finland) to south (Southern Finland) and hemiboreal (Central Estonia) conditions. Decomposition (percent mass loss) of FWD with diameter $\leq 10 \mathrm{~mm}$ (twigs) and FWD with diameter $>10 \mathrm{~mm}$ (branches) was measured using the litter bag method over 1-4 year periods. Overall, decomposition rates increased from north to south, the rate constants ( $k$ values) varying from 0.128 to 0.188 year $^{-1}$ and from 0.066 to 0.127 year $^{-1}$ for twigs and branches, respectively. On average, twigs had lost $34 \%, 19 \%$ and $19 \%$, and branches $25 \%, 17 \%$ and $11 \%$ of their initial mass after 2 years of decomposition at the hemiboreal, south boreal and north boreal sites, respectively. After 4 years at the south boreal site the values were $48 \%$ for twigs and $42 \%$ for branches. Based on earlier studies, we suggest that the decomposition rates that we determined may be used for estimating Scots pine FWD decomposition in the boreal zone, also in upland forests. Explanatory models accounted for $50.4 \%$ and $71.2 \%$ of the total variation in FWD decomposition rates when the first two and all years were considered, respectively. The variables most related to FWD decomposition included the initial ash, water extractives and Klason lignin content of litter, and cumulative site precipitation minus potential evapotranspiration. Simulations of inputs and decomposition of Scots pine FWD and needle litter in south boreal conditions over a 60 year period showed that $72 \mathrm{~g} \cdot \mathrm{m}^{-2}$ of organic matter from FWD vs. $365 \mathrm{~g} \cdot \mathrm{m}^{-2}$ from needles accumulated in the forest floor. The annual inputs varied from $5.7 \mathrm{~g} \cdot \mathrm{m}^{-2}$ to $15.6 \mathrm{~g} \cdot \mathrm{m}^{-2}$ and from $92 \mathrm{~g} \cdot \mathrm{m}^{-2}$ to $152 \mathrm{~g} \cdot \mathrm{m}^{-2}$ for FWD and needles, respectively. Each thinning caused an increase in FWD inputs, up to $510 \mathrm{~g} \cdot \mathrm{m}^{-2}$, while the needle inputs did not change dramatically. Because the annual FWD inputs were lowered following the thinnings, the overall effect of thinnings on $\mathrm{C}$ accumulation from FWD was slightly negative. The contribution of FWD to soil $\mathrm{C}$ accumulation, relative to needle litter, seems to be rather minor in boreal Scots pine forests.
\end{abstract}

Key words: climate, fine woody debris (FWD), decomposition, forestry-drained peatlands, litter quality, Scots pine, management simulations 


\section{Introduction}

Scots pine (Pinus sylvestris L.) is a common tree species in Eurasian boreal and temperate forests with considerable litter inputs into the forest floor. Although the proportion of fine woody debris (FWD) in aboveground litterfall is much smaller than that of foliar litter (Laiho et al., 2003), FWD may be of great importance regarding the C cycle and storage in forest ecosystems. FWD is richer in lignin and poorer in $\mathrm{N}$ than foliar litter and is therefore expected to be more recalcitrant (e.g., Berg et al., 1982). Taylor et al. (1991) observed very low rates of mass loss for conifer FWD during 4 years in three Rocky Mountain forests. Correspondingly, (Laiho and Prescott, 1999) estimated that FWD contributed 27\%-44\% of organic matter accumulation in the forest floor in those forests, where the inputs of FWD ranged from 103 to $150 \mathrm{~g} \mathrm{~m}^{-2}$ year $^{-1}$. On the other hand, it has been suggested that $\mathrm{N}$-poor materials will eventually decompose more completely, i.e. have higher maximum mass loss, than N-rich materials (e.g., Berg, 2000; Berg and Meentemeyer, 2002).

Peatland forests are important reserves of $\mathrm{C}$ that deserve special attention in all countries where even a small percentage of peatlands is found, due to the overproportional role of peat soils in greenhouse gas (GHG) emissions (Byrne et al., 2004). Even though peatlands are facilitated by sequestration of organic matter into the anoxic layer, most of the $\mathrm{C}$ fluxes take place in the relatively thin oxic layers near the surface. In the oxic surface layers of peatlands, the rates of litter decomposition may not in fact generally differ from those found in mineral soil sites for the same litter types (Coulson and Butterfield, 1978; Moore et al., 2002).

To determine the factors controlling decomposition rates of various plant litters, the litter bag method has been commonly applied (e.g., Melillo et al., 1982; Aerts and Caluwe, 1997b; Berg et al., 2000; Prescott, 2005). The general conclusion has been that litter decomposition rates are controlled by a hierarchy of interacting physical, chemical and biotic factors. Climate, determining decomposition rates at a broad (regional) scale, mainly sets the general limits of decomposition through physiological restrictions on the activities of decomposing organisms (Heneghan et al., 1999). In the boreal and temperate zones, decomposition rates generally increase from cold to warm and from dry to moist conditions, as demonstrated with many litter types (Palosuo et al., 2005) in the validation of the Yasso decomposition model (Liski et al., 2005). Chemical quality of the substrate and/or site specific factors, such as microtopography and fertility, then determine the rates at which the organisms can operate within these restrictions (Coûteaux et al., 1995; Berg and Meentemeyer, 2002).

While the decomposition of pine needles has been widely studied in both laboratory and field conditions (e.g., Johansson, 1994; Berg, 2000a; McTiernan et al., 2003; KurzBesson et al., 2006), no information is available on the decomposition rates of pine FWD except for that obtained from studies on harvesting residues (Hyvönen et al., 2000; Palviainen et al., 2004). This material may differ from "true litter" in many respects, e.g. in its chemical quality, having not undergone translocation and delayed shedding after senescence.

In this study we aimed to determine decomposition rates of FWD in pine-dominated boreal peatland forests. We postulated that the initial chemical quality and environmental factors have the main effects on decomposition. Our hypotheses were that mass loss rates would increase: 1. from coarser to finer FWD in line with differences in their initial quality, 2. from dry to moist microsites, 3. from nutrient-poor to nutrient-rich sites, and 4. from northern to southern climate. Our approach was to test hypotheses 1.-3. in an extensive field experiment in south boreal conditions and to address the climatic impacts with less extensive experiments in north boreal and hemiboreal conditions. Finally, we simulated the inputs and decomposition of Scots pine FWD and needle litter in the south boreal conditions over a 60 
year period to estimate the magnitude of the $\mathrm{C}$ fluxes of FWD relative to the better known needle litter fraction.

\section{Material and methods}

\subsection{Study sites}

FWD decomposition was studied in three peatland sites drained for forestry in climatically different parts of the boreal vegetation zone: north boreal (Northern Finland), south boreal (Southern Finland), and hemiboreal (Estonia) (Table 1a).

The south boreal site was situated in Padasjoki at the Vesijako Research Forest of the Finnish Forest Research Institute. The site was originally a treed mire with an ombrotrophic centre and minerotrophic lagg. The mire was drained for forestry in 1915. This site served as the main experimental site for defining FWD decomposition rates, with the longest period of monitoring and two plots representing different initial (pre-drainage) nutrient regimes: ombrotrophic and minerotrophic. Ombrotrophic sites receive nutrients from wet and dry deposition only, while minerotrophic sites additionally receive groundwater inputs carrying nutrients from the mineral soils in the catchment. The ombrotrophic plot represented dwarf shrub type (DsT; Laine, 1989) and the minerotrophic plot Vaccinium vitis-idea type (VT) at the time of the study. These are the most common drained pine sites in Southern Finland. The peat nitrogen $(\mathrm{N})$ concentration was fairly low in the surface peat of both plots (Table $1 \mathrm{~b}$ ). The tree stand consisted mostly of Scots pine (83\%), the rest being Norway spruce (Picea abies) and downy birch (Betula pubescens). The peat depth varied from ca. 100 (VT) to over $300 \mathrm{~cm}$ (DsT).

The north boreal site was situated in Rovaniemi at the Kivalo Research Forest of the Finnish Forest Research Institute. This site served as the northern extent for defining FWD decomposition rates in the boreal climate. The site was originally a treed minerotrophic mire. It was drained for forestry in 1933. At the time of the study it was classified as Vaccinium myrtillus type (MT, Laine, 1989) peatland forest, and represented the most commonly drained pine sites in the northern conditions. The tree stand was dominated by Scots pine, with some Norway spruce and downy birch in the understorey. The peat layer was fairly thin, $30-90 \mathrm{~cm}$.

The hemiboreal site was situated at Väätsa, Central Estonia. This site served as the southern extent in the boreal climate. The site was originally a rich fen and was drained for forestry in 1959. The resultant tree stand consisted mostly of Scots pine with an understorey of Norway spruce and downy birch at the time of the study and no thinning or wood removal had occurred. The site was very rich in $\mathrm{N}$ and calcium $(\mathrm{Ca})$, and was classified as herb-rich type (HrT, Table $1 \mathrm{a}+\mathrm{b}$ ) according to Laine (1989). Peat depth varied from 235 to $300 \mathrm{~cm}$. Due to the southern location and the initial site type, the site was considered to represent high availability of $\mathrm{N}$ and $\mathrm{P}$, and, potentially, the highest mass loss rates within the boreal zone.

Weather conditions at the three sites during the measurement years are presented in Table 2. See Minkkinen et al. (2007) for more detailed site descriptions.

\subsection{The litter material}

Dead branches were harvested from 3 to 4 live Scots pines at each site. The trees were located at least $10 \mathrm{~m}$ apart, and represented different DBH (diameter at $1.3 \mathrm{~m}$ ) classes. Branches from different trees were kept separate during the experiment to capture the possible between-tree variation in litter quality (e.g., Madritch and Hunter, 2005) and/or decomposition rates. They were divided into two size classes: thin branches (diameter $\leq 10 \mathrm{~mm}$ ), henceforward called twigs, and thicker branches (diameter > $10 \mathrm{~mm}$; maximum diameter ca. $30 \mathrm{~mm}$ ), henceforward called branches. The litter was air dried at room temperature $\left(20{ }^{\circ} \mathrm{C}\right)$ to a 
constant mass (about $92-94 \%$ dry mass) and used for litter bag preparation. The same material was used for litter quality analyses according to Karsisto et al. (2003).

The quality analyses were selected to divide the litter into organic chemical fractions that are considered to decompose at different rates (Berg et al., 1982). These fractions included extractable (soluble) substances, holocellulose (sum of cellulose and hemicelluloses), sulphuric acid non-hydrolysable fraction (Klason lignin) and sulphuric acid soluble lignin. The amounts of extractable substances were determined gravimetrically by sonicating milled samples with a solvent in a sonicator water bath and weighing the samples after filtration and drying. Mass loss during each extraction was considered to be the content of extractable compounds. Dichloromethane was used to remove nonpolar extractives (e.g. fats, oils, resins, waxes, plant pigments, fatty alcohols, fatty acids) and acetone, ethanol and hot water to remove polar extractives (e.g. soluble carbohydrates, ketones, pectins, tannins); basics in Ryan et al. (1990), Wieder and Starr (1998).

Extractive-free samples were then hydrolysed in sulphuric acid. Primary hydrolysis of each $0.3 \mathrm{~g}$ sample was performed with $1.00 \mathrm{ml} 72 \% \mathrm{H}_{2} \mathrm{SO}_{4}$ for $1 \mathrm{~h}$ in a sonicator bath at 30 ${ }^{\circ} \mathrm{C}$. Hydrolysates were then diluted to $4 \% \mathrm{H}_{2} \mathrm{SO}_{4}$ by ultrapure water and a secondary hydrolysis was performed for $1 \mathrm{~h}$ at $120{ }^{\circ} \mathrm{C}$ and pressure 1.2 bar. The non-hydrolysable residue was defined as Klason lignin after filtration and drying. The filtrates (hydrolysates) from the Klason lignin determination were diluted by ultrapure water (1:4, i.e., such a rate that the resulting absorbance readings fell between 0.2 and 0.7) and absorption of the solutions was measured at $203 \mathrm{~nm}$ with Shimadzu UV-2401 PC UV-VIS Recording Spectrophotometer, using the 1-cm light path cuvette. Sulphuric acid of the same concentration as in the samples was used as a reference blank. The percentage of acid soluble lignin was calculated according to Ehrman (1996).

Holocellulose (sum of cellulose and hemicelluloses) was determined from extractivefree samples using the sodium chlorite method (Quarmby and Allen, 1989).

Concentrations of $\mathrm{C}$ and $\mathrm{N}$ were determined from air-dried samples with a LECO CHN-1000 analyzer, and the concentrations of other elements with an ICP-emission spectrometer (ARL 3580) after dry-ashing and dissolution of the ash with hydrochloric acid $(\mathrm{HCl})$. Dry mass content was determined by drying subsamples at $105{ }^{\circ} \mathrm{C}$ overnight and the ash content by combustion at $550^{\circ} \mathrm{C}$ for $4 \mathrm{~h}$.

\subsection{Decomposition measurements}

Decomposition was studied using the litter bag method. Each litter bag contained on average $13 \mathrm{~g}$ and $44 \mathrm{~g}$ of air dried litter for twigs and branches, respectively, cut into 10-20 cm long pieces. The mesh size of the nylon bags used was $1 \mathrm{x} 1 \mathrm{~mm}$ to prevent physical losses of the material but to allow small mesofauna typical of the sites (Silvan et al., 2000) to enter the bags. For each site, 18-20 replicates per size class were prepared for annual recovery (Table $3)$.

For the litter bag incubation, 40 locations were selected randomly at the south boreal (20 at each of the two plots) and north boreal sites. Some of the locations were on low hummocks while others on the general surface level (Table 3). With the general surface we mean the dominant, more or less even level not representing hummock or depression. The surface difference between the hummocks and the general surface was approximately $10 \mathrm{~cm}$ and served as a test of moisture impact on FWD decomposition as the hummocks are generally drier microsites. At the hemiboreal site, 38 locations were selected for the litter bag incubation. Half of them were located in furrows resultant from ploughing as site preparation for planting the Scots pine seedlings following the drainage of the site. The surface difference between the general surface and the furrows was approximately $20 \mathrm{~cm}$ and served again as a test of moisture impact on FWD decomposition as the general surface locations are drier. At 
each site, about half of the locations were used for incubation of twigs and half for incubation of branches (Table 3).

In the field the litter material was remoistened and the litter bags were placed horizontally on the forest floor where the litter would naturally fall. In the course of time, they became naturally covered by new litter and moss growth, where mosses were present. Installation took place in the autumn of 2000, 2001 and 2003 at the south boreal, north boreal and hemiboreal site, respectively.

The mass loss was then measured from annually recovered subsets of litter bags. Each year, a subset of 38 or 40 litter bags (one from each incubation location, see Table 3) was retrieved from each site and transported directly to a laboratory where it was kept frozen till further processing. The content was cleaned by removing all materials that had penetrated the bags, dried to a constant mass at $40{ }^{\circ} \mathrm{C}$ and weighed. Total dry mass content was determined by drying subsamples at $105{ }^{\circ} \mathrm{C}$ overnight. Decomposition rates were expressed as total dry mass loss after each incubation period.

Incubation periods presented here are 1-4, 1-3 and 1-2 years for the south boreal, north boreal and hemiboreal sites, respectively, and originate from an ongoing long-term study. The experiment is designed for 10-year monitoring of Scots pine FWD decomposition.

\subsection{Environmental parameters}

Air temperature at $2 \mathrm{~m}$ above the soil surface, and soil temperature at $5 \mathrm{~cm}$ below the soil surface were monitored at each site/plot. Daily mean temperatures, annual mean temperatures and the effective temperature sums over $0{ }^{\circ} \mathrm{C}$ threshold for the specific incubation periods for air/soil were calculated from these local measurements. If local data were not available for some dates, we used measurements of the Finnish Meteorological Institute (FMI) or the Estonian Meteorological and Hydrological Institute (EMHI) from the closest weather station as estimates of air temperature, while mean daily soil temperature values were linearly interpolated from the values of adjacent measurements.

Monthly precipitation for the "summer" months (here defined as April - October), annual summer precipitation sums and summer precipitation sums for the specific incubation periods were calculated for each site. Local monitoring data were available for the south and north boreal sites. Some periodic gaps in data at the south boreal site were complemented with data from the FMI weather station at Lammi, Iso-Evo. In the hemiboreal site, we used data from the EMHI weather station at Türi.

Potential evapotranspiration (PET) was calculated for each summer month (April October) using the Thornthwaite water balance method (Thornthwaite, 1948), which is based on an empirical relationship between potential evapotranspiration and mean air temperature. Precipitation minus potential evapotranspiration (PREC-PET) values was used to estimate the monthly site water balance. Positive values indicated that precipitation exceeded PET while negative values indicated possible site moisture deficiency. For each site and incubation period three types of summer PREC-PET sums were calculated: 1) positive values only 2) negative values only and 3) all values of monthly PREC-PET.

Soil samples were collected using a box sampler (cross section 4 x $6 \mathrm{~cm}$ ) from the 0 $10 \mathrm{~cm}$ surface peat layer. Subsamples from $12,8,6$, and 10 systematically chosen sampling points at the general surface level were composited to represent the north boreal, south boreal DsT, south boreal VT, and hemiboreal site, respectively. Element concentrations were analyzed as for the litter materials.

\subsection{Statistical analyses}

Relations among the litter quality parameters were first explored by principal component analysis (PCA) and correlation analysis. To determine the within- and between-site variation 
in FWD quality, two-way ANOVA followed by Tukey's post-hoc comparison was carried out. Site and FWD size class were used as grouping factors. To estimate the proportion of variation in FWD quality explainable by twig and branch differences and/or between-site differences, redundancy analysis (RDA) was carried out. To analyze whether there was significant variation in mass loss of twigs and branches incubated at different microsites and/or at different site nutrient regimes within the south boreal site, repeated-measures ANOVA was carried out. This analysis was performed separately for twigs and branches of a given site; microtopography and plot were used as grouping factors, and time as a repeated factor. PCA and RDA were performed using Canoco for Windows version 4.5 (Biometris, 2003), correlation analysis and ANOVA using Statistica for Windows version 6.1 (StatSoft, 2003).

Models were constructed to identify factors controlling the variation in the mass loss of FWD. Because of the hierarchical data structure, a mixed (multilevel) model approach was used (Goldstein, 1995). We identified four hierarchical levels, or levels of clustering, in the data: (1) site, (2) tree, (3) incubation location, (4) recovery cohort (year 1, year 2 etc.; this made the model follow a repeated measures design).

The mixed models had the following form:

$$
y_{i j k l}=\alpha_{i j k l}+\beta_{1} x_{1 i j k l}+\beta_{2} x_{2 i j k l}+\ldots+\beta_{n} x_{n i j k l}+f_{l}+v_{k l}+u_{j k l}+\varepsilon_{i j k l}
$$

where $y_{i j k l}$ is the cumulative mass loss for the incubation period $i$ within incubation location $j$ for FWD from tree $k$ in site $l$. The fixed part consists of intercept $\alpha$, and site, weather and litter quality characteristics $x_{1 i j k l}-x_{n i j k l}$ (all levels shown for simplicity, even though some variables varied only at the site level) with parameters $\beta_{1}-\beta_{n}$. In the random part, $f_{l}$ is the variance derived from site $l, v_{k l}$ is the variance associated with tree $k$ in site $l, u_{j k l}$ is the variance associated with different incubation locations $j$ of tree $k$ in site $l$, and $\varepsilon_{i j k l}$ accounts for the within-incubation location variation between different incubation periods.

Variation in mass-loss rates of litter deriving from different trees within a site was estimated based on the variance associated with the tree level: a significant variance component would indicate significant inter-tree variation. For examining inter-tree variation in chemical parameters, simple variance component models with a constant only in the fixed part were also constructed.

The estimation was done using MLwiN software (Rasbash et al., 2004), which estimates the fixed and random parameters simultaneously. We applied the restricted iterative generalized least square (RIGLS) method. The significance of the variables was evaluated based on their parameter standard error (parameter value should be at least twice its SE). The value of $-2 \times \log$-likelihood was used to compare models of increasing complexity. The factors included in the final models were selected based on the amount of explained total variation in FWD mass loss and the value of $-2 \times \log$-likelihood. The goodness of fit was further evaluated based on residuals. To find which factors influenced FWD mass loss specifically in its early stage and which had an effect on the overall pattern, different models were constructed for the first two years of decomposition, and for the whole data set, respectively.

Simple decomposition rate coefficients were estimated separately for both FWD size classes, as well as for FWD in general (both sizes together), at each site using the exponential decay function (Olson, 1963)

$$
Y_{t}=Y_{0} e^{-k t}
$$

where $Y_{t}=$ mass remaining at time $\mathrm{t}(\%), Y_{0}=$ mass remaining at time $0,-k=$ decomposition rate constant, and $t=$ time (days). The function was fit using nonlinear regression with least squares estimation by Gauss-Newton method that computes exact derivatives, using SYSTAT 10 for Windows. The goodness of fit was evaluated based on residuals. Since the rates were 
estimated for all sites separately, data structure did not require special attention in this analysis.

Litter quality and mass loss data without any transformation were used for all the statistical analyses. We tested an angular transformation of mass loss data $\left(x^{\prime}=\operatorname{arcsine} \sqrt{ } x\right.$ where $x$ are mass loss values in range 0-1) as it is recommended to use to remedy slight nonnormality associated with percentage values (Knudsen and Curtis, 1947). As the transformation did not provide any improvements to our data, nontransformed values were used.

\subsection{Simulations}

For estimating the long-term impacts of FWD and foliar litter from Scots pine trees on soil C, we simulated the development of a model stand representing typical, well-managed Scots pine stands on drained VT sites in south boreal conditions. The initial DBH (diameter at 1.3 $\mathrm{m})$ distribution of the model stand for the onset of the simulation was reconstructed from the data records of an extensive survey on forestry-drained peatland sites in Finland (Keltikangas et al., 1986). In its initial stage, the model stand was to represent a situation where the stand has already stabilized following the rapid increase in stem number and heterogeneity in stand structure following water level drawdown (Sarkkola et al., 2005), but would still await canopy closure and the expected increase in FWD litterfall (Laiho et al., 2003). This was considered to be the case at about 20 years after the first-time ditching with the following stand parameters characterizing the model stand: $1900 \mathrm{stems} \mathrm{ha}^{-1}, 16 \mathrm{~m}^{2} \mathrm{ha}^{-1}$ of basal area, $12 \mathrm{~m}$ of stand dominant height, and $90 \mathrm{~m}^{3} \mathrm{ha}^{-1}$ of stem volume. The model stand included an admixture of downy birch but only Scots pine litter is considered in the following.

We then used the MOTTI stand simulator (Hynynen et al., 2005) to predict the dynamics of the model stand at five-year time steps. In MOTTI, the specific models for drained peatland stands consist of i) individual-tree basal-area growth models (Hökkä et al., 1997), ii) height-diameter models (Hökkä, 1997), and iii) tree mortality models (Jutras et al., 2003). The simulation was continued until regeneration maturity, i.e. when the trees' mean $\mathrm{DBH}$, weighted by tree basal area, reached $26 \mathrm{~cm}$. Two thinning cuttings were applied, first at $28 \mathrm{~m}^{2} \mathrm{ha}^{-1} / 16 \mathrm{~m}$ and again at $28 \mathrm{~m}^{2} \mathrm{ha}^{-1} / 18 \mathrm{~m}$ of basal area/dominant height, respectively.

At the onset and after each five-year simulation step we applied Marklund's (1988) biomass functions, using tree $\mathrm{DBH}$ and height as explanatory variables, to the Scots pine DBH distribution predicted by MOTTI in order to obtain tree-wise estimates of live branch and foliage biomass for the pine trees. We then applied dynamic turn-over rates depending on tree DBH and stand density, based on the model of Lehtonen et al. (2004), to estimate FWD from tree-level live branch biomass, as well as an empirically estimated turn-over rate of 0.3 for needle biomass, based on the measured stand-level litterfall and foliar biomass data from the drained VT sites of Laiho et al. (2003). The litterfall estimates where then summed up to stand-level and divided evenly to annual estimates for the five-year period. Thinnings were assumed to be performed according to the stem-only harvesting method, thus leaving the branches and needles of the harvested trees as harvesting residues or litter on the site. These additional inputs of FWD and needle litter were estimated using biomass functions (Marklund, 1988) and added as such to the annual litter input data.

The annual FWD and needle inputs were decomposed using the $k$ values determined in this study and published $k$ values ( Berg and McClaugherty, 2003), respectively. On an $a$ posteriori basis, we applied the FWD $k$ value to the harvesting residue branches. The firstyear litter cohort was decomposed for 60 years, the second form 59, and so forth. The cumulative differences between inputs and decomposition losses for each year were summed up to represent organic matter accumulation from the different fractions during the 60-year simulation period. 


\section{Results}

\subsection{Variation in litter quality}

Differences between twig and branch litters accounted for a large part (35\%) of the total variation in the initial FWD quality. Twigs had a higher content of ash, extractable compounds and nutrients, and a lower content of holocellulose, compared to branches (Table 4, Fig. 1). Some of the quality parameters varied among the sites (Table 4, Fig. 1) and this accounted for $29 \%$ of the total variation in the initial FWD quality. Variation in the chemical quality did not follow the geographical gradient. Within a given site, the litter quality did not vary significantly between individual trees.

Several intercorrelations among the quality parameters were evident (Table 5, Fig. 1). Ash concentration was positively correlated with the concentrations of all the main nutrients, except Mn. Most of the nutrients were in a positive mutual correlation. NPE and acid soluble lignin showed similar correlations to the other quality parameters (Table 5).

\subsection{Variation in mass loss rates}

Mass loss did not vary between the ombrotrophic vs. minerotrophic plots within the south boreal site. Thus, their data were combined to represent the site in further analyses.

Twigs decomposed faster than branches at each site (Fig. 2). In the north boreal and the hemiboreal site the difference in mass loss rates of twigs and branches was already large during the first two years of decomposition, whereas in the south boreal site it emerged only after 3 years of decomposition. FWD derived from different trees within a given site did not vary in their mass loss rates.

Site microtopography, considered as a source of variation in site moisture conditions potentially affecting mass loss, influenced the decomposition of twigs in the north boreal site. There, the overall mass loss was higher for twigs incubated at the general surface level, compared to those incubated on low hummocks ( $p=0.045, F=4.632$; Fig. 2$)$. A similar difference was observed at the south boreal site during the third incubation period (Fig 2a), which included the driest summer of the four in terms of the precipitation sum from June to September.

Overall, decomposition was faster in the hemiboreal site than in either of the boreal sites (Fig. 3). Decomposition of twigs was initially higher in the north boreal site than in the south boreal site, but later the pattern reversed. From the second year onwards, the decomposition rate of branches was lowest in the north boreal site. The exponential decay function (Eq. 2) fit the data reasonably well (Fig. 3). The decomposition rate constant [year ${ }^{-1}$ ] varied from 0.128 to 0.188 for twigs and from 0.066 to 0.127 for branches (Table 6).

\subsection{Factors controlling the mass loss}

The initial litter quality accounted for more of the variation in FWD mass loss than the site weather and soil parameters, and this pattern was stronger during the first 2 years of decomposition. Mass loss was enhanced by a higher content of ash and water extractives, while a higher content of Klason lignin slowed down the rate of decomposition in the longer term (Table 7). Of the site weather parameters, PREC-PET sum proved to be the best mass loss predictor. Precipitation surplus (positive values of PREC-PET) enhanced FWD mass loss. The "best" models that generally described FWD decomposition (Table 7) explained $50.4 \%$ and $71.2 \%$ of the total variation in mass loss during the early decomposition stage (first two years) and overall (all years), respectively. Site differences in FWD decomposition could be partly explained by the surface peat Mn concentration (negative correlation with the 
mass loss; not shown here) or by the surface peat $\mathrm{N}$ and $\mathrm{P}$ concentration for the early decomposition of twigs (positive correlation with the mass loss; not shown here).

\subsection{Simulations}

The simulated cumulative litter inputs over 60 years were $1455 \mathrm{~g} \cdot \mathrm{m}^{-2}$ for FWD and $7784 \mathrm{~g} \cdot \mathrm{m}^{-}$

${ }^{2}$ for needles (Fig. 4). From these inputs, $72 \mathrm{~g} \cdot \mathrm{m}^{-2}(5.0 \%)$ and $365 \mathrm{~g} \cdot \mathrm{m}^{-2}(4.7 \%)$ remained after 60 years for FWD and needles, respectively. The annual inputs varied from $5.7 \mathrm{~g} \cdot \mathrm{m}^{-2}$ to 15.6 $\mathrm{g} \cdot \mathrm{m}^{-2}$ and from $92 \mathrm{~g} \cdot \mathrm{m}^{-2}$ to $152 \mathrm{~g} \cdot \mathrm{m}^{-2}$ for FWD and needles, respectively. Each thinning caused a major increase in FWD inputs, up to $510 \mathrm{~g} \cdot \mathrm{m}^{-2}$, while the needle inputs did not change as dramatically.

\section{Discussion}

\subsection{Litter quality effects on decomposition}

The morphological differences between twigs and branches were reflected as surprisingly clear differences in litter quality. Potential reasons include the different proportion of bark and wood: twigs had a higher proportion of bark which contains lower concentrations of holocellulose and greater concentrations of nutrients and lignin compared to wood (Hyvönen et al., 2000; Ganjegunte et al., 2004).

Pine twigs and branches do not get senescent and shed on the forest floor seasonally like foliage litter. Instead, they stay on trees for various lengths of time in spite of their mortality, depending on their diameters and the position in a tree, as well as on the stand density, site topography and weather conditions. During this period FWD get leached and decomposed to a various extent, leading to changes in quality and to a great heterogeneity of the material that is then shed onto the forest floor as litter. Tree genotype has been reported to influence tree leaf litter chemistry as well as various wood properties (Madritch and Hunter, 2002; Hannrup et al., 2004; Madritch and Hunter, 2005; Mäkinen et al., 2007). We found significant variation neither in FWD quality nor in mass loss rates among different trees of a given site. The inherent heterogeneity in FWD described above might mask any such variations. Also, FWD quality may in general be less variable than that of, e.g., foliar litter.

A clear climatic influence on the initial quality has been observed for foliar litter (Berg et al., 2000, Liu et al., 2006). We had only 3 sites forming the climatic gradient and no clear pattern was found between the initial FWD quality and climatic factors. However, sitedependent variation did occur in some litter quality parameters, such as WE, which was included in our explanatory models. Therefore, we tested whether the litter quality effects were actually just site effects, but that was not the case.

Initial quality of FWD, especially in terms of water extractives and ash, turned out to be the most powerful mass loss predictor, and this finding was consistent with other decomposition studies; the water soluble fraction has been found to control early decomposition of various litter types (Gholz et al., 2000; Preston and Trofymow, 2000; Trofymow et al., 2002) and several decomposition models use it as one of the predicting variables for litter mass loss (e.g., (Moorhead et al., 1999; Liski et al., 2005). It is generally assumed that when litter is exposed to decomposing microorganisms, the soluble components are attacked first and are therefore the first to disappear. Substrates rich in easily soluble compounds thus decompose rapidly. For FWD, the soluble fraction is small and thus its predictive power was somewhat surprising.

The strong positive influence of ash content on FWD mass loss may reflect an overall limiting role of nutrients in their inorganic form in the decomposition process as ash correlated with most of the nutrients (Table 5). Initial content of N, P or Mn regulated mass loss in many decomposition studies (e.g. Aerts and Caluwe, 1997b; Berg, 2000b; Hoorens et 
al., 2003; Berg et al., 2007). When we tested the effect of each single nutrient on FWD decomposition, however, we found no significant relation. This might have been due to the small between-site variation in litter nutrient levels (Table 4) (see Johansson, 1994).

Nutrient concentrations generally increase as wood decomposition proceeds (e.g., Alban and Pastor, 1993; Krankina et al., 1999). The C and N concentrations of our twig and branch litter were similar to the concentrations reported for fresh twigs and branches from mineral soil sites (Hyvönen et al., 2000; Palviainen et al., 2004). Concentrations of P in turn were several times lower in the litter material, indicating that $\mathrm{P}$ was partly relocated to the living biomass before senescence, and/or was leached/mineralized when the litter material was still attached to the tree. This resulted in a high N:P ratio and thus $\mathrm{P}$ could be the limiting factor for FWD decomposition at all sites (Güsewell and Freeman, 2005).

Klason lignin, providing a rough integral of the most insoluble lignin, cutin and tannin structures, had no significant influence on FWD mass loss during the first two years of decomposition, but did have an effect on the overall decomposition pattern. Klason lignin thus may regulate FWD mass loss rather in later stages, which would be in accordance with the "3-phase decomposition model" for foliar litter (Berg and Matzner, 1997) where the latter two stages are lignin regulated. Negative relationships between lignin-based indicators of litter quality and mass loss have been shown in numerous studies based in both field and laboratory (e.g., Meentemeyer, 1978; Johansson, 1994; Preston and Trofymow, 2000; Berg and Meentemeyer, 2002; Trofymow et al., 2002); however, the effect of Klason lignin on FWD mass loss was not very strong. Relationships with lignin seem to be weaker for materials with generally high lignin contents, such as woody litters (Taylor et al., 1991). Also, some wood decomposers specifically target lignin, and colonization by different microbes may cause variation in the decomposition dynamics over time.

\subsection{Environmental effects on FWD decomposition}

In our sites, both temperature and precipitation increased southwards, and it is thus difficult to separate their effects. Temperature, as indicated by air $\mathrm{T}$ sums over the incubation period, showed a smaller effect on FWD mass loss than precipitation in the model analysis (not shown). Sites characterized by a cold climate still experience significant mass loss (Moore, 1983), partly since snow cover moderates temperatures in the litter layer (Hardy et al., 2001) and partly due to the presence of microbial communities active under low temperatures (Schmidt and Lipson, 2004).

The single weather-based variable most related to FWD mass loss was summer precipitation minus PET sum (PREC-PET), which combined the effects of both summer precipitation and mean air $\mathrm{T}$. The best results were obtained when sums of positive PRECPET values, that indicate moisture surplus, were used in the models. PET and precipitation, as well as actual evapotranspiration (AET) which incorporates these two variables, have also been shown to correlate with foliar litter mass loss across a wide range of climatic conditions (Berg et al., 1993; Johansson, 1994; Berg et al., 2000; Gholz et al., 2000; Berg and Meentemeyer, 2002).

Between-site moisture conditions, as indicated by variation in the April-October sum of precipitation among sites, had an impact on FWD decomposition since its early stages (not shown). In contrast, within-site variation in moisture conditions, induced by site microtopography, did not influence FWD mass loss, except for twigs in the north boreal site that decomposed faster on the supposedly moister general surface level (Fig. 2). Smalldiameter materials are more prone to drying, which may explain why the response was seen in the twigs (Edmonds, 1987). Interestingly, the effect was seen in the northernmost site only. Precipitation was in fact lower there than in the other sites; however, the lower evapotranspiration is supposed to keep the conditions more humid. Similarly, twigs 
decomposed faster in the moister microsite in the southern boreal site during a dry summer (Fig. 2).

Moisture has a strongly nonlinear effect on decomposition - both extremely high and low moisture contents can limit decomposer activity (Boddy, 1983; Chen et al., 2000). High water levels, and consequent anoxia in pristine peatlands, are responsible for slow decomposition and peat accumulation, while in drained peatlands, dryness of the litter on the peat surface can limit decomposition (Martikainen et al., 1995; Laiho et al., 2004). We supposed the summer drought to be the limiting factor for FWD decomposition in our sites, particularly during June, July and August. We tested the effects of the precipitation sum of each of those months separately, but the gross water supply, represented by the summer (April-October) precipitation sum, turned out to be more related to FWD mass loss. It should be noted in this context that our litter bags were placed on top of the forest floor and thus, the materials reached ground contact - and became in fact gradually covered by natural litter and/or mosses - rather soon. Of the real litterfall, some FWD would most likely become perched in patches of shrubs etc., remain drier than FWD in contact with the ground, and decompose slower.

In the case that litterbags are installed in the autumn, as was in our experiment, precipitation during the following winter may have an effect on the early decomposition stage through leaching of easily soluble compounds (Trofymow et al., 2002). This was not tested for FWD as winter precipitation data from our study sites were not available; in any case, the initial content of such compounds in our materials was low.

We supposed $\mathrm{N}$ and $\mathrm{P}$ to be more readily available at the minerotrophic plot within the south boreal site, which would enhance microbial activities and thus instigate greater mass loss; however, we found no such effect on FWD decomposition. Contrastingly, heterotrophic soil respiration (SR) originating from old organic matter, i.e., peat and old (> 2 years) litter, was indeed greater at the more nutrient rich plot (Minkkinen et al., 2007). Old organic matter may behave differently from the newly shed litter, especially FWD poor in N. Such different behaviour is also reflected in the climatic response:

Again in contrast to our results, Minkkinen et al. (2007) found the SR from old organic matter to be highest in the north (see also Bringmark and Bringmark, 1991). The north boreal site experiences longer periods with soil temperature at $5 \mathrm{~cm}$ below the soil surface higher than $0{ }^{\circ} \mathrm{C}$ during the winter because of better insulation by the snow cover, and this may play a significant role in soil respiration, but obviously not in the decomposition of FWD on the soil surface. The number of days with soil $\mathrm{T}>0{ }^{\circ} \mathrm{C}$ during winter did not affect FWD mass loss, results not shown. The microbial communities decomposing peat seem to respond differently to variation in environmental conditions, such as winter temperatures or soil nutrient regimes, compared to those decomposing FWD in the forest floor. Dalias et al. (2001) found that a substrate initially decomposing at a higher temperature was in later stages degraded more slowly than the same substrate initially degraded at a lower temperature. As FWD was still a continuously changing substrate, the effects of climate on its decomposition may change with time.

\subsection{FWD decomposition rates}

We found no previous results on mass loss of Scots pine twig and branch litter, but rather only those coming from harvesting residue decomposition studies following clear-cutting. The mass loss for initially fresh Scots pine or Norway spruce branches was 25-41\% after 3-4 years following clear-cutting in Sweden or Finland (Lundmark-Thelin and Johansson, 1997; Hyvönen et al., 2000; Palviainen et al., 2004) and 30\% after 3 years in uncut forest (Palviainen et al., 2004). These values are surprisingly well within the range of our results, 
even though these materials differ in many respects from FWD, as do the soil and site microclimate characteristics between forest and clear-cut.

Our materials showed a rather linear mass loss over the study period. Decomposition of organic matter has often been described with the exponential decay, i.e. negative exponential function, following Olson (1963), which has the advantage that the parameter $k$ may be interpreted as the decomposition rate. The fit of our FWD materials was acceptable but not optimal (Figure 3). We estimated the parameters so that they may be applied in decomposition models or ecosystem models in general until better estimates are available. However, we want to emphasize that the function should not be applied uncritically without evaluation of residuals (also, Taylor et al., 1989; Prescott, 2005). Our estimates cover a wide range of conditions from north to hemiboreal. Based on earlier comparative studies (Coulson and Butterfield, 1978; Moore et al., 2002), we suggest that the rates may be applied for both peatland and mineral soil pine stands.

\subsection{C flux of FWD}

While the percentage of accumulated mass of FWD and needle inputs over 60 years was similar (about 5\%), in absolute terms the difference between the two litter types was obvious with FWD inputs and accumulation comprising about $20 \%$ of those of the needle fraction. FWD inputs displayed great variation due to the thinning management, which resulted in high accumulation of FWD at the site after the thinning. The thinning inputs, however, decomposed in about 20 years when the remaining FWD mass at the site reached the prethinning level. Because the annual FWD inputs were lowered following the thinnings, the overall effect of thinnings on $\mathrm{C}$ accumulation from FWD was actually slightly negative. The contribution of FWD to soil $\mathrm{C}$ accumulation, at least relative to needle litter, seems to be more minor in boreal Scots pine forests than in some other coniferous forest types (Laiho and Prescott, 1998). Longer-term decomposition results are needed to validate the behaviour of FWD in the forest floor, however.

\section{Acknowledgments}

This study was supported by the Academy of Finland projects 104425 and 106197 . We thank Soili Kojola for performing the litter input simulations and Satu Repo, Markku Pastila, Alison Gillette, Tapani Hänninen, Pekka Helminen, and Timo Törmänen for their valuable help with the field and laboratory work, Meeri Pearson for correcting the language, and the three reviewers for their helpful comments on the manuscript. 


\section{References}

Aerts, R., De Caluwe, H., 1997a. Initial litter respiration as indicator for long-term leaf litter decomposition of Carex species. Oikos 80, 353-361.

Aerts, R., De Caluwe, H., 1997b. Nutritional and plant-mediated controls on leaf litter decomposition of Carex species. Ecology 78, 244-260.

Alban, D.H., Pastor, J., 1993. Decomposition of aspen, spruce and pine boles on two sites in Minnesota. Can. J. For. Res. 23, 1744-1749.

Berg, B., 2000a. Initial rates and limit values for decomposition of Scots pine and Norway spruce needle litter: a synthesis for $\mathrm{N}$-fertilized forest stands. Can. J. For. Res. 30, 122 135.

Berg, B., 2000b. Litter decomposition and organic matter turnover in northern forest soils. Forest Ecol. Manage. 133, 13-22.

Berg, B., Berg, M.P., Bottner, P., Box, E., Breymeyer, A., Calvo de Anta, R., Couteaux, M., Escudero, A., Gallardo, A., Kratz, W., Madeira, M., Mälkönen, E., McClaugherty, C., Meentemeyer, V., Muñoz, F., Piussi, P., Remacle, J., Virzo De Santo, A., 1993. Litter Mass Loss Rates in Pine Forests of Europe and Eastern United States: Some Relationships with Climate and Litter Quality. Biogeochem. 20, 127-159.

Berg, B., Hannus, K., Popoff, T., Theander, O., 1982. Changes in organic-chemical components during decomposition. Long-term decomposition in a Scots pine forest I. Can. J. Bot. 60, 1310-1319.

Berg, B., Johansson, M.-B., Meentemeyer, V., 2000. Litter decomposition in a transect of Norway spruce forests: substrate quality and climate control. Can. J. For. Res. 30, 11361147.

Berg, B., Matzner, E., 1997. Effect of N deposition on decomposition of plant litter and soil organic matter in forest systems. Environ. Rev. 5, 1-25.

Berg, B. and McClaugherty, C., 2003. Plant litter - decomposition, humus formation, carbon sequestration. Springer-Verlag, Berlin. 286.

Berg, B., Meentemeyer, V., 2002. Litter quality in a north European transect versus carbon storage potential. Plant Soil 242, 83-92.

Berg, B., Steffen, K., McClaugherty, C., 2007. Litter decomposition rate is dependent on litter Mn concentrations. Biogeochem. 82, 29-39.

Bringmark, E., Bringmark, L., 1991. Large-scale pattern of mor layer degradability in Sweden measured as standardized respiration. Allard, B., Borén, H., Grimvaland, A., (Eds.). In: Humic Substances in Aquatic and Terrestrial Environment. Springer-Verlag, Berlin, pp. 255-259.

Byrne, K.A., Chojnicki, B., Christensen, T.R., Drösler, M., Freibauer, A., Friborg, T., Frolking, S., Lindroth, A., Mailhammer, J., Malmer, N., Selin, P., Turunen, J., Valentini, R., Zetterberg, L., 2004. EU Peatlands: Current carbon stocks and trace gas fluxes. Carboeurope GHG, Report SS 41. 58 pp.

Coulson, J.C., Butterfield, J., 1978. An investigation of the biotic factors determining the rates of plant decomposition on blanket bog. J. Ecol. 66, 631-650.

Coûteaux, M., Bottner, P., Berg, B., 1995. Litter decomposition, climate and litter quality. Trends Ecol. Evol., 10, 63-66.

Dalias, P., Anderson, J.M., Bottner, P., Coûteaux, M., 2001. Long-term effects of temperature on carbon mineralisation processes. Soil Biology and Biochemistry, 33, 1049-1057.

Edmonds, R.L., 1987. Decomposition rates and nutrient dynamics in small-diameter woody litter in four forest ecosystems in Washington, U.S.A. Can. J. For. Res. 17, 499-509.

Ehrman, T., 1996. Determination of acid-soluble lignin in biomass. In: Laboratory Analytical Procedures No. 004. Golden, CO, National Renewable Energy Laboratory, 1-7. 
Ganjegunte, G.K., Condron, L.M., Clinton, P.W., Davis, M.R., Mahieu, N., 2004. Decomposition and nutrient release from radiata pine (Pinus radiata) coarse woody debris. Forest Ecol. Manage. 187, 197-211.

Gholz, H.L., Wedin, D.A., Smitherman, S.M., Harmon, M.E., Parton, W.J., 2000. Long-term dynamics of pine and hardwood litter in contrasting environments: toward a global model of decomposition. Global Change Biol. 6, 751-765.

Goldstein H., 1995. Multilevel Statistical Models. Kendall's Library of Statistics 3. Hodder Arnold, London.

Güsewell, S., Freeman, C., 2005. Nutrient limitation and enzyme activities during litter decomposition of nine wetland species in relation to litter $\mathrm{N}: \mathrm{P}$ ratios. Functional Ecology 19, 582-593.

Hannrup, B., Cahalan, C., Chantre, G., Grabner, M., Karlsson, B., Lebayon, I., Lloyd Jones, G., Müller, U., Pereira, H., Rodrigues, J.C., Rosner, S., Rozenberg, P., Wilhelmsson, L., Wimmer, R., 2004. Genetic parameters of growth and wood quality traits in Picea abies. Scand. J. For. Res. 19, 14-29.

Hardy, J.P., Groffman, P.M., Fitzhugh, R.D., Henry, K.S., Welman, A.T., Demers, J.D., Fahey, T.J., Driscoll, C.T., Tierney, G.L., Nolan, S., 2001. Snow Depth Manipulation and Its Influence on Soil Frost and Water Dynamics in a Northern Hardwood Forest. Biogeochem. 56, 151-174.

Heneghan, L., Coleman, D., Zou, X., Crossley, D.,Jr., Haines, B., 1999. Soil microarthropod contributions to decomposition dynamics: tropical-temperate comparisons of a single substrate. Ecology 80, 1873-1882.

Hökkä, H. 1997. Height-diameter curves with random intercepts and slopes for trees growing on drained peatlands. Forest Ecology and Management 97: 63-72.

Hökkä, H., Alenius, V., Penttilä, T. 1997. Individual-tree basal area growth models for Scots pine, pubescent birch and Norway spruce on drained peatlands in Finland. Silva Fennica 31(2): 161-178.

Hoorens, B., Aerts, R., Stroetenga, M., 2003. Does initial litter chemistry explain litter mixture effects on decomposition? Oecologia 137, 578-586.

Hynynen, J., Ahtikoski, A., Siitonen, J., Sievänen, R., Liski, J. 2005. Applying the MOTTI simulator to analyse the effect of alternative management schedules on timber and nontimber production. Forest Ecology and Management 207: 5-18.

Hyvönen, R., Olsson, B.A., Lundkvist, H., Staaf, H., 2000. Decomposition and nutrient release from Picea abies (L.) Karst. and Pinus sylvestris L. logging residues. For. Ecol. Manage. 126, 97-112.

Johansson, M., 1994. Decomposition rates of Scots pine needle litter related to site properties, litter quality, and climate. Can. J. For. Res. 24, 1771-1781.

Jutras, S., Hökkä, H., Alenius, V., Salminen, H. 2003. Modeling mortality of individual trees in drained peatland sites in Finland. Silva Fennica 37(2): 235-251.

Karsisto, M., Savitski, M., Kitunen, V., Penttilä, T., Laine, J., Laiho, R., 2003. Quantification of organic fractions in litter and peat organic matter. In: Honkanen, J.O., Koponen, P.S., (Eds.), Proceedings of Sixth Finnish Conference of Environmental Sciences: Current Perspectives in Environmental Science and Technology. Finnish Society for Environmental Sciences, pp. 135-137.

Keltikangas, M., Laine, J., Puttonen, P., Seppälä, K. 1986. Vuosina 1930-1978 metsäojitetut suot: ojitusalueiden inventoinnin tuloksia. Summary: Peatlands drained for forestry during 1930-1978: results from field surveys of drained areas. Acta Forestalia Fennica 193: 1-94.

Knudsen, L.F., Curtis, J.M., 1947. The Use of the Angular Transformation in Biological Assays. Journal of the American Statistical Association 42, 282-296. 
Krankina, O.N., Harmon, M.E., Griazkin, A.V., 1999. Nutrient stores and dynamics of woody detritus in a boreal forest: modeling potential implications at the stand level. Can. J. For. Res. 29, 20-32.

Kurz-Besson, C., Coûteaux, M.M., Berg, B., Remacle, J., Ribeiro, C., Romanyà, J., Thiéry, J.M., 2006. A climate response function explaining most of the variation of the forest floor needle mass and the needle decomposition in pine forests across Europe. Plant Soil 285, 97-114.

Laiho, R., Laine, J., Trettin, C.C., Finér, L., 2004. Scots pine litter decomposition along drainage succession and soil nutrient gradients in peatland forests, and the effects of inter-annual weather variation. Soil Biol. Biochem. 36, 1095-1109.

Laiho, R., Prescott, C.E., 1999. The contribution of coarse woody debris to carbon, nitrogen, and phosphorus cycles in three Rocky Mountain coniferous forests. Can. J. For. Res. 29, 1592-1603.

Laiho, R., Vasander, H., Penttilä, T., Laine, J., 2003. Dynamics of plant-mediated organic matter and nutrient cycling following water-level drawdown in boreal peatlands. Global Biogeochem. Cycles 17, 1053.

Laine, J., 1989. Metsäojitettujen soiden luokittelu (Summary: Classification of peatlands drained for forestry). Suo 40, 37-51.

Liski, J., Palosuo, T., Peltoniemi, M., Sievänen, R., 2005. Carbon and decomposition model Yasso for forest soils. Ecological Modelling 189, 168-182.

Liu, C., Berg, B., Kutsch, W., Westman, C.J., Ilvesniemi, H., Shen, X., Shen, G., Chen, X.D., 2006. Leaf litter nitrogen concentration as related to climatic factors in Eurasian forests. Global Ecology and Biogeography 15, 438-444.

Lundmark-Thelin, A., Johansson, M., 1997. Influence of mechanical site preparation on decomposition and nutrient dynamics of Norway spruce (Picea abies (L.) Karst.) needle litter and slash needles. For. Ecol. Manage., 96, 101-110.

Madritch, M.D., Hunter, M.D., 2002. Phenotypic diversity influences ecosystem functioning in an oak sandhills community. Ecology 83, 2084-2090.

Madritch, M.D., Hunter, M.D., 2005. Phenotypic variation in oak litter influences short- and long-term nutrient cycling through litter chemistry. Soil Biol. Biochem. 37, 319-327.

Mäkinen, H., Jaakkola, T., Piispanen, R., Saranpää, P., 2007. Predicting wood and tracheid properties of Norway spruce. Forest Ecol. Manage. 241, 175-188.

Marklund, L.G. 1988. Biomassafunktioner för tall, gran och björk i Sverige. Summary: Biomass functions for pine, spruce and birch in Sweden. Sveriges Lantbruksuniversitetet, Institutionen för skogstaxering, Rapport 45. Umeå. 73 p.

Martikainen, P.J., Nykänen, H., Alm, J., Silvola, J., 1995. Change in fluxes of carbon dioxide, methane and nitrous oxide due to forest drainage of mire sites of different trophy. Plant Soil 168-169, 571-577.

McTiernan, K.B., Couteaux, M.-., Berg, B., Berg, M.P., Calvo de Anta, R., Gallardo, A., Kratz, W., Piussi, P., Remacle, J., Virzo de Santo, A., 2003. Changes in chemical composition of Pinus sylvestris needle litter during decomposition along a European coniferous forest climatic transect. Soil Biol. Biochem. 35, 801-812.

Meentemeyer, V., 1978. Macroclimate and lignin control of decomposition rates. Ecology 59, 465-472.

Melillo, J.M., Aber, J.D., Muratore, J.F., 1982. Nitrogen and Lignin Control of Hardwood Leaf Litter Decomposition Dynamics. Ecology 63, 621-626.

Minkkinen, K., Laine, J., Shurpali, N.J., Mäkiranta, P., Alm, J., Penttilä, T., 2007. Heterotrophic soil respiration in forestry-drained peatlands. Boreal Env. Res. 12, 115126. 
Moore, T.R., Bubier, J.L., Frolking, S.E., Lafleur, P.M., Roulet, N.T., 2002. Plant biomass and production and $\mathrm{CO}_{2}$ exchange in an ombrotrophic bog. J. Ecol. 90, 25-36.

Moorhead, D.L., Currie, W.S., Rastetter, E.B., Parton, W.J., Harmon, M.E., 1999. Climate and litter quality controls on decompositon: an analysis of modeling approaches. Global Biogeochem. Cycles 13, 575-589.

Olson, J.S., 1963. Energy storage and the balance of producers and the decomposers in ecological systems. Ecology 14, 322-331.

Palosuo, T., Liski, J., Trofymow, J.A., Titus, B.D., 2005. Litter decomposition affected by climate and litter quality-Testing the Yasso model with litterbag data from the Canadian intersite decomposition experiment. Ecological Modelling 189, 183-198.

Palviainen, M., Finér, L., Kurka, A.-., Mannerkoski, H., Piirainen, S., Starr, M., 2004. Decomposition and nutrient release from logging residues after clear-cutting of mixed boreal forest. Plant Soil 263, 53-67.

Prescott, C.E., 2005. Do rates of litter decomposition tell us anything we really need to know? Forest Ecol. Manage. 220, 66-74.

Preston, C.M., Trofymow, J.A., CIDET Working Group, 2000. Variability in litter quality and its relationship to litter decay in Canadian forests. Can. J. Bot. 78, 1269-1287.

Quarmby, C., Allen, S.E., 1989. Organic constituents. In: Allen, S.E., (Ed.). Chemical Analysis of Ecological Materials. Wiley, New York, pp. 160-201.

Rasbash J., Steele F., Browne W., Prosser B., 2004. A User's Guide to MlwiN. Version 2.0. Centre for Multilevel Modelling, Institute of Education, University of London.

Ryan, M.G., Melillo, J.M., Ricca, A., 1990. A comparison of methods for determining proximate carbon fractions of forest litter. Can. J. For. Res. 20, 166-171.

Sarkkola, S., Hökkä, H., Laiho, R., Päivänen, J., and Penttilä, T. 2005. Stand structural dynamics on drained peatlands dominated by Scots pine. Forest Ecology and Management 206: 135-152.

Schmidt, S.K., Lipson, D.A., 2004. Microbial growth under the snow: Implications for nutrient and allelochemical availability in temperate soils. Plant Soil 259, 1-7.

Silvan, N., Laiho, R., Vasander, H., 2000. Changes in mesofauna abundance in peat soils drained for forestry. For Ecol Manage 133, 127-133.

Taylor, B.R., Parkinson, D., Parsons, W.J.F., 1989. Nitrogen and lignin content as predictors of litter decay rates: a microcosm test. Ecology 70, 97-104.

Taylor, B.R., Prescott, C.E., Parsons, W.J.F., Parkinson, D., 1991. Substrate control of litter decomposition in four Rocky Mountain coniferous forests. Can. J. Bot. 69, 2242-2250.

Thornthwaite, C.W., 1948. An approach toward a rational classification of climate. Geographic Review 38, 55-94.

Trofymow, J.A., Moore, T.R., Titus, B., Prescott, C., Morrison, I., Siltanen, M., Smith, S., Fyles, J., Wein, R., Camire, C., Duschene, L., Kozak, L., Kranabetter, M., Visser, S., 2002. Rates of litter decomposition over 6 years in Canadian forests: influence of litter quality and climate. Can. J. For. Res. 32, 789-804.

Wieder, R.K., Starr, S.T., 1998. Quantitative determination of organic fractions in highly organic, Sphagnum peat soils. Commun Soil Sci. Plant Anal. 29, 847-857. 
Table 1a. General description of the study sites.

\begin{tabular}{|c|c|c|c|c|c|c|c|c|c|}
\hline Site & Plot & Coordinates & m.a.s.l. & Site type ${ }^{(I}$ & $\begin{array}{l}\mathrm{N} \\
\left(\text { stems ha }^{-1}\right)\end{array}$ & $\begin{array}{l}\text { Basal area } \\
\left(\mathrm{m}^{-2} \mathrm{ha}^{-1}\right)\end{array}$ & $\begin{array}{l}\text { Hdom } \\
(\mathrm{m})\end{array}$ & $\begin{array}{l}\text { Stand volume } \\
\left(\mathrm{m}^{-2} \mathrm{ha}^{-1}\right) \mathrm{l}\end{array}$ & Drainage year \\
\hline North boreal & & $66^{\circ} 21^{\prime} \mathrm{N}, 26^{\circ} 37^{\prime} \mathrm{E}$ & 180 & MT & 1025 & 20.0 & 14.3 & 139 & $1933,-50,-85$ \\
\hline South boreal & DsT & $61^{\circ} 22^{\prime} \mathrm{N}, 25^{\circ} 07^{\prime} \mathrm{E}$ & 115 & DsT & 670 & 18.5 & 20.6 & 165 & $1915,-33,-54$ \\
\hline South boreal & VT & $61^{\circ} 22^{\prime} \mathrm{N}, 25^{\circ} 07^{\prime} \mathrm{E}$ & 115 & VT & 880 & 24.0 & 20.2 & 209 & $1915,-33,-54$ \\
\hline Hemiboreal & & $58^{\circ} 59^{\prime} \mathrm{N}, 25^{\circ} 27^{\prime} \mathrm{E}$ & 78 & HrT & 1709 & 25.5 & 16.5 & 187 & 1959 \\
\hline
\end{tabular}

${ }^{1)}$ HrT - herb-rich type; MT - Vaccinium myrtillus type; VT - Vaccinium vitis-idaea type; DsT - dwarf shrub type (see Laine 1989, Westman and Laiho 2003).

$\mathrm{N}$, number of stems; Hdom, dominant height; $\mathrm{V}_{\mathrm{i}}$, stand volume increment; m.a.s.l., metres above sea level

Table 1b. Soil nutrient contents at the study sites $\left(\mathrm{mg} \cdot \mathrm{g}^{-1}\right.$ of dry mass)

\begin{tabular}{lcccccccccccc}
\hline Site & Plot & Ash & $\mathrm{C}$ & $\mathrm{N}$ & $\mathrm{P}$ & $\mathrm{Al}$ & $\mathrm{B}$ & $\mathrm{Ca}$ & $\mathrm{Fe}$ & $\mathrm{K}$ & $\mathrm{Mg}$ & $\mathrm{Mn}$ \\
\hline North boreal & & 68.4 & 542 & 24.6 & 1.72 & 4.47 & 0.0016 & 2.97 & 11.46 & 0.26 & 0.36 & 0.013 \\
South boreal & DsT & 34.8 & 528 & 13.9 & 0.67 & 0.71 & 0.0030 & 4.17 & 0.79 & 0.52 & 0.54 & 0.188 \\
South boreal & VT & 44.2 & 521 & 16.9 & 0.77 & 0.86 & 0.0028 & 5.54 & 1.14 & 0.50 & 0.62 & 0.337 \\
Hemiboreal & & 61.9 & 487 & 33.7 & 0.86 & 1.15 & 0.0044 & 11.49 & 3.78 & 0.31 & 0.60 & 0.074 \\
\hline
\end{tabular}

See table 1a for the explanation of DsT and VT. 
Table 2. Weather conditions at the sites during the measurement years, and averages for periods 1961-90 (north and south boreal sites) and 19912005 (all sites; that was the longest period available for the hemiboreal site).

\begin{tabular}{|c|c|c|c|c|c|c|c|c|c|c|}
\hline Site & Years & $\begin{array}{l}\text { T_air } \\
\left({ }^{\circ} \mathrm{C}\right) \\
\text { mean } \\
\text { annual }\end{array}$ & $\begin{array}{l}\text { T_air }\left({ }^{\circ} \mathrm{C}\right) \\
\text { mean } \\
\text { summer }{ }^{(1}\end{array}$ & $\begin{array}{l}\text { T_air } \\
\text { sum } \\
\text { (d.d. > } \\
\left.5^{\circ} \mathrm{C}\right)\end{array}$ & $\begin{array}{l}\text { Precipitation }(\mathrm{mm}) \\
\text { summer }^{(1} \text { (year) }\end{array}$ & $\begin{array}{l}\text { P_PETpos } \\
(\mathrm{mm}) \text { summer }^{(1}\end{array}$ & $\begin{array}{l}\text { P_PETneg } \\
(\mathrm{mm}) \text { summer }^{(1}\end{array}$ & $\begin{array}{l}\text { T_soil } 5 \mathrm{~cm} \\
\left({ }^{\circ} \mathrm{C}\right) \\
\text { mean } \\
\text { annual }\end{array}$ & $\begin{array}{l}\text { T_soil } 5 \mathrm{~cm} \\
\left({ }^{\circ} \mathrm{C}\right) \\
\text { mean } \\
\text { summer }\end{array}$ & $\begin{array}{l}\text { Tsum_soil } \\
5 \mathrm{~cm} \\
\left(\text { d.d. }>0^{\circ} \mathrm{C}\right)\end{array}$ \\
\hline North & 2002 & 0.4 & 9.4 & 1117 & 322 & 41 & -148 & 4.5 & 8.9 & 1710 \\
\hline \multirow[t]{4}{*}{ boreal } & 2003 & 1.4 & 9.6 & 1026 & 384 & 76 & -70 & 4.6 & 8.9 & 1721 \\
\hline & 2004 & 1.5 & 9.3 & 961 & 540 & 164 & -36 & 4.5 & 8.7 & 1675 \\
\hline & 1961-1990 & -0.2 & 8.5 & $865^{a}$ & $339(538)^{a}$ & & & & & \\
\hline & 1991-2005 & 0.8 & 8.8 & $927^{\mathrm{a}}$ & $397(598)^{a}$ & & & & & \\
\hline South & 2001 & 3.6 & 11.7 & 1319 & 437 & 89 & -64 & 5.7 & 9.9 & 2075 \\
\hline \multirow[t]{5}{*}{ boreal } & 2002 & 3.8 & 10.8 & 1336 & 393 & 131 & -136 & 5.3 & 10.2 & 1875 \\
\hline & 2003 & 3.8 & 11.2 & 1254 & 551 & 227 & -77 & 5.2 & 10.0 & 1836 \\
\hline & 2004 & 4.0 & 11.7 & 1300 & 597 & 216 & -59 & 5.7 & 10.7 & 1960 \\
\hline & 1961-1990 & 3.4 & 11.2 & $1239^{a}$ & $373(601)^{\mathrm{a}}$ & & & & & \\
\hline & 1991-2005 & 4.3 & 11.5 & $1295^{\mathrm{a}}$ & $403(618)^{a}$ & & & & & \\
\hline \multirow[t]{3}{*}{ Hemiboreal } & 2004 & 4.9 & 11.3 & 1241 & 421 & 102 & -98 & 5.4 & 10.5 & 2041 \\
\hline & 2005 & 4.9 & 10.3 & 1263 & 511 & 152 & -54 & 6.0 & 10.0 & 2235 \\
\hline & 1991-2005 & 4.8 & 12.1 & $1421^{b}$ & $454(725)^{b}$ & & & & & \\
\hline
\end{tabular}

${ }^{1)}$ May-October

${ }^{a}$ Estimated from FMI data according to Ojansuu \& Henttonen (1983)

${ }^{\mathrm{b}}$ According to EMHI data from Türi weather station 
Table 3. Experimental layout

\begin{tabular}{lllcc}
\hline Site & Plot & Size & $\begin{array}{c}\text { Samples per annual recovery } \\
\text { (number of trees) }\end{array}$ & $\begin{array}{c}\text { Annual samples per } \\
\text { general surface/hummock } \\
\text { (furrow }{ }^{(1 / g e n e r a l ~ s u r f a c e) ~}\end{array}$ \\
\hline North boreal & & Twigs & $20(4)$ & $13 / 7$ \\
& Branches & $20(5)$ & $9 / 11$ \\
South boreal & DsT & Twigs & $10(2)$ & $6 / 4$ \\
& & Branches & $10(2)$ & $7 / 3$ \\
& VT & Twigs & $10(2)$ & $5 / 5$ \\
Hemiboreal & & Branches & $10(2)$ & $4 / 6$ \\
& & Twigs & $20(4)$ & $(10 / 10)$ \\
& Branches & $18(4)$ & $(9 / 9)$ \\
\hline
\end{tabular}

${ }^{1)}$ only in hemiboreal site, resultant from previous ploughing

Twigs, FWD with diameter $\leq 10 \mathrm{~mm}$; Branches, FWD with diameter $>10 \mathrm{~mm}$. See table 1a for the explanation of DsT and VT.

Table 4. Initial chemical quality of FWD (mg. $\mathrm{g}^{-1}$ of dry mass)

\begin{tabular}{|c|c|c|c|c|c|c|}
\hline & \multicolumn{2}{|c|}{ North boreal site } & \multicolumn{2}{|c|}{ South boreal site } & \multicolumn{2}{|c|}{ Hemiboreal site } \\
\hline & Twigs & Branches & Twigs & Branches & Twigs & Branches \\
\hline $\mathrm{n}$ & 4 & 5 & 4 & 5 & 4 & 4 \\
\hline Ash & $7.9(0.9)^{* *}$ & $3.4(0.3)^{* *}$ & $5.2(1.0)$ & $2.4(0.5)$ & $7.4(0.5)^{*}$ & $4.1(0.5)^{*}$ \\
\hline NPE & $71.6(8.7)^{*}$ & $31.4(5.4)^{*}$ & $62.7(4.0)$ & $33.7(4.2)$ & $87.6(10.1)^{*}$ & $46.5(5.0)^{*}$ \\
\hline $\mathrm{AE}$ & $6.4(1.2)$ & $3.6(1.7)$ & $7.1(1.5)$ & $5.8(1.2)$ & $7.4(0.8)$ & $3.1(0.4)$ \\
\hline $\mathrm{EE}$ & $19.3(1.4)^{\mathrm{b}}$ & $14.2(1.1)^{\mathrm{B}}$ & $33.5(2.7)^{\mathrm{a}}$ & $31.4(1.9)^{\mathrm{A}}$ & $7.4(0.5)^{\mathrm{c}}$ & $4.5(0.1)^{\mathrm{C}}$ \\
\hline WE & $15.8(2.3)^{\mathrm{b}}$ & $11.4(0.4)^{\mathrm{B}}$ & $23.6(2.4)^{\mathrm{a}}$ & $22.1(1.5)^{\mathrm{A}}$ & $24.1(1.0)^{\mathrm{a}}$ & $19.0(0.6)^{\mathrm{A}}$ \\
\hline Kl.lig & $429(6.2)$ & $427(2.7)$ & $432(7.0)$ & $423(4.3)$ & $436(8.7)$ & $433(7.8)$ \\
\hline Sol.lig & $9.0(0.6)$ & $7.3(0.3)$ & $8.6(0.6)$ & $7.7(0.2)$ & $10.6(0.4)^{*}$ & $8.4(0.4)^{*}$ \\
\hline Holl & $569(18.5)^{* *}$ & $702(15.5)^{* * \mathrm{~B}}$ & $542(14.7)^{*}$ & $611(8.3)^{* \mathrm{~A}}$ & $513(18.5)^{* *}$ & $622(11.0) * *^{\mathrm{A}}$ \\
\hline $\mathrm{C}$ & $527(3.9)^{* \mathrm{~b}}$ & $512.9(1.8)^{* \mathrm{~B}}$ & $538(1.8)$ & $528(1.4)^{\mathrm{A}}$ & $544(4.6)^{\mathrm{a}}$ & $533(2.7)^{\mathrm{A}}$ \\
\hline $\mathrm{N}$ & $3.7(0.4)^{* * \mathrm{~b}}$ & $2.0(0.1)^{* * \mathrm{~B}}$ & $4.1(0.2)^{* *}$ & $2.1(0.1)^{* *}$ & $5.0(0.4)^{* *^{\mathrm{a}}}$ & $3.1(0.3)^{* * \mathrm{~A}}$ \\
\hline $\mathrm{C} / \mathrm{N}$ & $146(12.9)^{* *}$ & $262(14.7)^{* * \mathrm{~A}}$ & $133(5.3)^{* *}$ & $255(7.4)^{* * \mathrm{~A}}$ & $111(6.8)^{*}$ & $174(14.2)^{* \mathrm{~B}}$ \\
\hline $\mathrm{N} / \mathrm{lig}$ & $0.009(0.001)^{* * a}$ & $0.005(0.0003)^{* *^{\mathrm{A}}}$ & $0.009(0.0005)^{* *}$ & $0.005(0.0002)^{* *}$ & $0.011(0.001)^{* * \mathrm{~b}}$ & $0.007(0.001)^{* * \mathrm{~B}}$ \\
\hline $\mathrm{Ca}$ & $2.50(0.34)^{* * b}$ & $0.98(0.12)^{* *}$ & $1.42(0.25)^{\mathrm{a}}$ & $0.70(0.14)^{\mathrm{A}}$ & $2.91(0.18)^{* \mathrm{~b}}$ & $1.89(0.24)^{* \mathrm{~B}}$ \\
\hline $\mathrm{K}$ & $0.33(0.05)^{*}$ & $0.14(0.04)^{*}$ & $0.21(0.03)$ & $0.12(0.02)$ & $0.28(0.042)$ & $0.17(0.04)$ \\
\hline $\mathrm{Mg}$ & $0.31(0.08)$ & $0.16(0.03)$ & $0.13(0.04)$ & $0.08(0.03)$ & $0.26(0.04)$ & $0.18(0.04)$ \\
\hline $\mathrm{Mn}$ & $0.12(0.03)^{\mathrm{b}}$ & $0.06(0.01)$ & $0.04(0.01)^{\mathrm{a}}$ & $0.03(0.01)$ & $0.03(0.004)^{\mathrm{a}}$ & $0.02(0.004)$ \\
\hline $\mathrm{P}$ & $0.19(0.03)^{* *}$ & $0.06(0.01)^{* *}$ & $0.13(0.01)^{*}$ & $0.05(0.004)^{*}$ & $0.21(0.03)^{*}$ & $0.10(0.01)^{*}$ \\
\hline
\end{tabular}

Means with s.e. in parentheses; $\mathrm{n}=$ number of samples (number of trees per site and FWD size category, see table 3); Twigs, FWD with diameter $\leq 10 \mathrm{~mm}$; Branches, FWD with diameter $>10 \mathrm{~mm}$; NPE = nonpolar (dichloromethane) extractives; $\mathrm{AE}=$ acetone extractives; $\mathrm{EE}=$ ethanol extractives; $\mathrm{WE}=$ hot water extractives; Kl.lig = Klason (acid insoluble) lignin; Sol.lig $=$ acid soluble lignin; Holl $=$ holocellulose (sum of cellulose and hemicelluloses); $\mathrm{C} / \mathrm{N}=$ carbon-to-nitrogen ratio; $\mathrm{N} / \mathrm{lig}=$ nitrogen-to-lignin ratio

* significant variation $(\mathrm{p}<0.05)$ between twigs and branches of the same site $(* * \mathrm{p}<0.001)$; a, b, c, different symbols show significant variation $(p<0.05)$ between twigs of the given sites; A,B,C different symbols show significant variation $(\mathrm{p}<0.05)$ between branches of the given sites. 
Table 5. Correlation matrix (Pearson's R) for the chemical quality parameters of FWD

\begin{tabular}{lrrrrrrrrrrrrrrrr}
\hline & \multicolumn{1}{c}{ Ash } & NPE & AE & EE & WE & Kl.lig & Sol.lig & Holl & C & N & C/N & N/lig & Ca & K & Mg & Mn \\
\hline NPE & $\mathbf{0 . 7 2}$ & & & & & & & & & & & & & & & \\
AE & 0.34 & 0.41 & & & & & & & & & & & & & & \\
EE & -0.15 & -0.12 & 0.34 & & & & & & & & & & & & & \\
WE & 0.23 & 0.37 & 0.52 & 0.32 & & & & & & & & & & & & \\
Kl.lig & 0.35 & 0.21 & 0.05 & -0.10 & 0.15 & & & & & & & & & & & \\
Sol.lig & $\mathbf{0 . 6 8}$ & 0.65 & 0.21 & -0.21 & 0.57 & 0.14 & & & & & & & & & & \\
Holl & -0.63 & $\mathbf{- 0 . 8 3}$ & -0.54 & -0.20 & $\mathbf{- 0 . 7 4}$ & -0.36 & $\mathbf{- 0 . 7 0}$ & & & & & & & & & \\
C & 0.40 & $\mathbf{0 . 7 9}$ & 0.46 & 0.00 & $\mathbf{0 . 7 2}$ & 0.22 & 0.58 & $\mathbf{- 0 . 8 7}$ & & & & & & & & \\
N & $\mathbf{0 . 7 1}$ & $\mathbf{0 . 8 7}$ & 0.46 & -0.14 & 0.49 & 0.41 & $\mathbf{0 . 7 2}$ & $\mathbf{- 0 . 8 6}$ & $\mathbf{0 . 8 0}$ & & & & & & & \\
C/N & $\mathbf{- 0 . 7 1}$ & $\mathbf{- 0 . 8 1}$ & -0.42 & 0.14 & -0.46 & -0.34 & $\mathbf{- 0 . 7 1}$ & $\mathbf{0 . 8 2}$ & $\mathbf{- 0 . 7 5}$ & $\mathbf{- 0 . 9 6}$ & & & & & & \\
N/lig & $\mathbf{0 . 7 1}$ & $\mathbf{0 . 8 8}$ & 0.48 & -0.13 & 0.49 & 0.32 & $\mathbf{0 . 7 3}$ & $\mathbf{- 0 . 8 5}$ & $\mathbf{0 . 8 0}$ & $\mathbf{1 . 0 0}$ & $\mathbf{- 0 . 9 6}$ & & & & & \\
Ca & $\mathbf{0 . 9 1}$ & $\mathbf{0 . 7 0}$ & 0.24 & -0.42 & 0.25 & 0.27 & $\mathbf{0 . 7 3}$ & -0.57 & 0.48 & $\mathbf{0 . 7 0}$ & $\mathbf{- 0 . 7 1}$ & $\mathbf{0 . 7 0}$ & & & & \\
K & $\mathbf{0 . 8 0}$ & 0.64 & 0.46 & -0.05 & 0.26 & 0.06 & 0.49 & -0.51 & 0.41 & 0.57 & -0.55 & 0.59 & $\mathbf{0 . 7 5}$ & & & \\
Mg & $\mathbf{0 . 7 5}$ & 0.47 & 0.15 & -0.31 & 0.10 & -0.07 & 0.61 & -0.31 & 0.18 & 0.37 & -0.38 & 0.39 & $\mathbf{0 . 7 7}$ & $\mathbf{0 . 7 6}$ & & \\
Mn & 0.49 & 0.19 & 0.08 & 0.05 & -0.25 & -0.18 & 0.21 & -0.01 & -0.23 & 0.03 & -0.06 & 0.05 & 0.31 & 0.55 & $\mathbf{0 . 7 5}$ & \\
P & $\mathbf{0 . 8 6}$ & $\mathbf{0 . 8 7}$ & 0.46 & -0.17 & 0.33 & 0.36 & $\mathbf{0 . 6 7}$ & $\mathbf{- 0 . 7 8}$ & $\mathbf{0 . 6 6}$ & $\mathbf{0 . 8 9}$ & $\mathbf{- 0 . 8 4}$ & $\mathbf{0 . 8 9}$ & $\mathbf{0 . 8 4}$ & $\mathbf{0 . 7 9}$ & 0.62 & 0.32 \\
\hline
\end{tabular}

Significant Pearson's R values $(\mathrm{p}<0.05)$ are in boldface. $\mathrm{n}=25$. See table 4 for the abbreviations. 
Table 6. Decomposition rate constants (k-values, year $\left.^{-1}\right)$, their asymptotic standard errors (a.s.e.) and 95\% Wald confidence intervals for both FWD size classes at each site as well as for FWD in general (both sizes together) .

\begin{tabular}{lllll}
\hline Site & $k$ & a.s.e. & \multicolumn{2}{c}{ Confidence interval } \\
Size class & & & & \\
& & & & \\
\hline North boreal & & & & \\
Twigs & 0.128 & 0.006 & 0.116 & 0.141 \\
Branches & 0.066 & 0.004 & 0.058 & 0.074 \\
FWD & 0.096 & 0.005 & 0.087 & 0.105 \\
South boreal & & & & \\
Twigs & 0.154 & 0.007 & 0.141 & 0.167 \\
Branches & 0.127 & 0.005 & 0.118 & 0.136 \\
FWD & 0.140 & 0.004 & 0.132 & 0.149 \\
Hemiboreal & & & & \\
Twigs & 0.188 & 0.008 & 0.172 & 0.203 \\
Branches & 0.129 & 0.006 & 0.116 & 0.142 \\
FWD & 0.159 & 0.006 & 0.147 & 0.171 \\
& & & & \\
\hline
\end{tabular}

Twigs, FWD with diameter $\leq 10 \mathrm{~mm}$; Branches, FWD with diameter $>10 \mathrm{~mm}$.

Table 7. Hierarchical models for FWD mass loss.

\begin{tabular}{lrlr}
\hline $\begin{array}{l}\text { Fixed part } \\
\text { Effect }\end{array}$ & Coefficient & $\begin{array}{l}\text { Random part } \\
\text { Effect }\end{array}$ & Variance component \\
\hline $\begin{array}{l}\text { Early decomp. model } \\
\text { (first two years) }\end{array}$ & & & \\
Constant & $-8.772(4.001)$ & Site & $29.165(24.167)$ \\
Ash & $8.604(2.406)$ & Tree & $0.051(0.984)$ \\
Water extractives & $5.445(1.513)$ & Incubation location & $7.539(3.001)$ \\
PREC-PET_positive & $0.077(0.005)$ & Recovery cohort & $22.825(2.972)$ \\
\hline Overall decomp. model & & & \\
(all years) & & & $0.201(1.009)$ \\
Constant & $38.962(19.762)$ & Site & $1.627(1.783)$ \\
Ash & $19.449(2.126)$ & Tree & $6.751(3.022)$ \\
Kl.lignin & $-0.952(0.467)$ & Incubation location & $40.548(3.689)$ \\
PREC-PET_positive & $0.062(0.002)$ & Recovery cohort & \\
\hline
\end{tabular}

Standard errors in parentheses. Ash, the initial ash content; Water extractives, the initial content of hot water extractives; Kl.lignin, the initial content of Klason lignin; PREC-PET_positive, sum of precipitation minus potential evapotranspiration values. Nonsignificant variance components are shown in italics. 
Fig. 1. Ordination diagram from principal component analysis (PCA) showing relations between chemical quality parameters of pine FWD. The first and second axes account for $55.4 \%$ and $16.0 \%$ of the total variation, respectively. TW, twigs (FWD with diameter $\leq 10$ $\mathrm{mm}$ ); BR, branches (FWD with diameter $>10 \mathrm{~mm}$ ). See Table 4 for the abbreviations. 

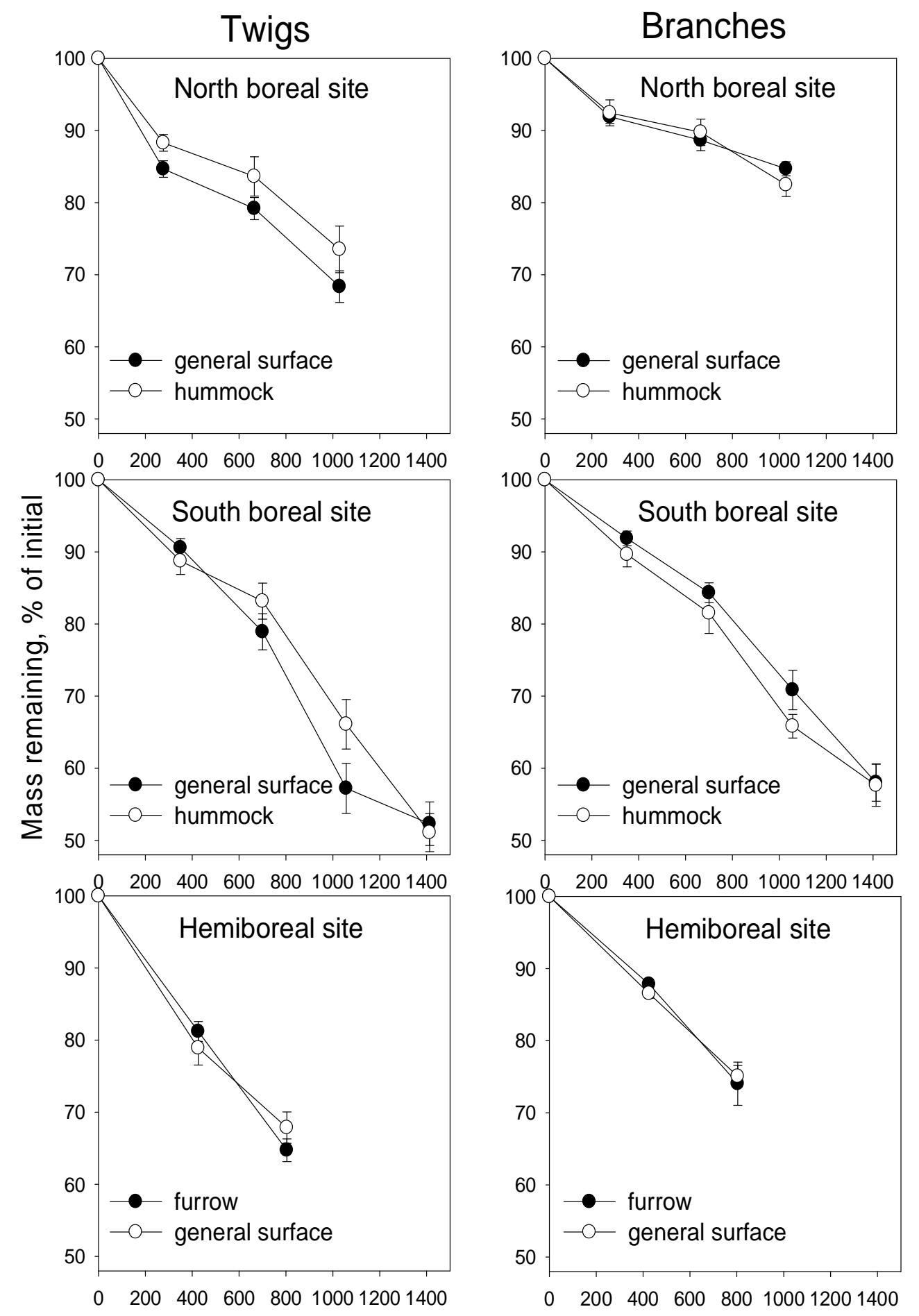

Time, days

Fig. 2. Scots pine FWD mass remaining following decomposition at potentially moister $(\bullet)$ and drier $(\circ)$ microsite within a given site. Data are presented as means \pm SE. Twigs, FWD with diameter $\leq 10 \mathrm{~mm}$; Branches, FWD with diameter $>10 \mathrm{~mm}$. The incubation started in year 2000, 2001, and 2003 for the south boreal, north boreal and the hemiboreal site, respectively. See Table 3 for the number of samples per site/size and annual recovery. 

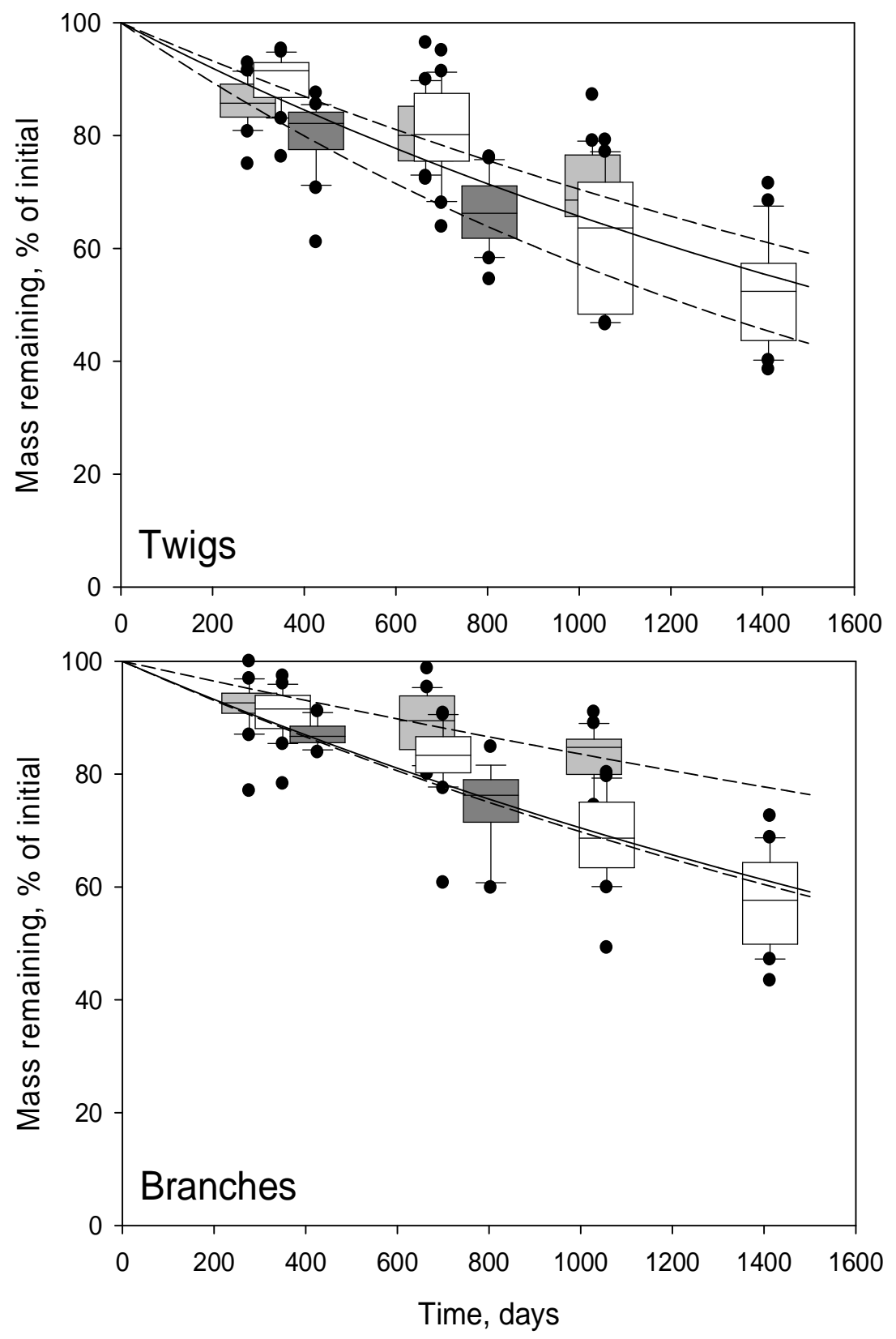

Fig. 3. Progress of decomposition depicted by box plots of remaining mass. The lower boundary of the box indicates the 25th percentile, a line within the box the median, and the upper boundary of the box the 75th percentile. Error bars indicate the 90th and 10th percentiles. Dots represent observations lying outside these limits.

Twigs, FWD with diameter $\leq 10 \mathrm{~mm}$; Branches, FWD with diameter $>10 \mathrm{~mm}$. South boreal $=$ white, North boreal $=$ light grey, Hemiboreal $=$ dark grey. Lines depict exponential decay functions plotted using the $k$-values shown in Table 6; solid line for south boreal, dashed lines for north boreal (upper) and hemiboreal (lower). See Table 3 for the number of samples per site/size and annual recovery. 


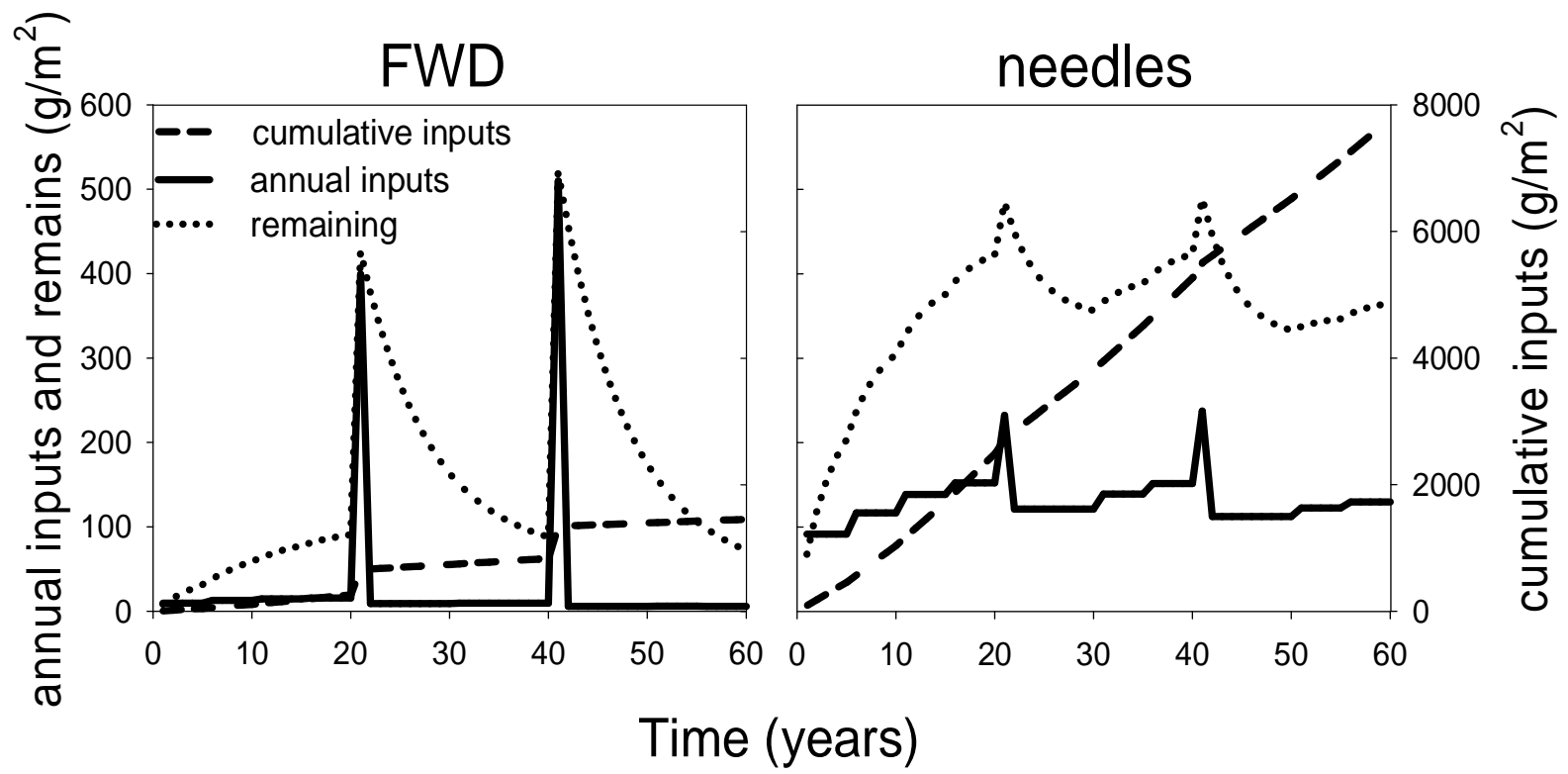

Fig. 4. Simulated annual and cumulative FWD and needle litter inputs, and the amounts remaining after simulated decomposition over a 60 -year period in a south boreal model stand. Simulated thinnings took place at years 20 and 40. Our general $k$ value for the south boreal site (0.14; Table 6) was applied for FWD decomposition, and 0.3 from Berg and McClaugherty (2003) for needle litter. Y-axis scale on left for annual inputs and amounts remaining, and on the right for cumulative inputs. 